\title{
KATA KERJA DAN HUBUNGAN LEKSIKAL DALAM IKLAN PRODUK KECANTIKAN WANITA
}

\author{
Indirawati ZAHID \\ Akademi Pengajian Melayu, Universiti Malaya \\ 50603, Kuala Lumpur \\ indirawati@um.edu.my
}

Manuscript received 11 February 2019

Manuscript accepted 24 April 2019

https://doi.org/10.33736/ils.1404.2019

\begin{abstract}
ABSTRAK
Iklan komersial adalah satu bentuk pembujukan dalam usaha mempengaruhi khalayak sasaran tentang pandangan atau keputusan membeli. Iklan produk kecantikan wanita merupakan salah satu daripadanya. Analisis dilakukan pada iklan dua jenama terkenal, iaitu D'HERBS dan Vida Beauty dengan fokus analisis pada kata kerja yang digunakan dalam slogan dan keterangan produk kecantikan muka. Kajian ini bertitik tolak daripada kajian yang telah dilakukan oleh Leech (1966) tentang kata kerja yang lazim digunakan dalam iklan. Kajian ini mempunyai dua objektif, iaitu mengenal pasti kata kerja yang lazim digunakan dan menganalisis hubungan leksikal yang wujud pada kata kerja yang lazim digunakan. Terdapat empat metod yang diaplikasi, iaitu kajian pustaka, syot layar, analisis frekuensi dan analisis teks. Dapatan kajian ini memperlihatkan antara kata kerja yang lazim digunakan dalam iklan kecantikan muka adalah "mencerah/mencerahkan", "merawat", "membantu" dan "melembap/melembapkan". Hubungan leksikal yang terbentuk daripada kekerapan kata kerja yang digunakan membentuk lapan kelompok sinonimi dan tiga kelompok antonimi. Kesimpulannya, pengiklan memilih kata yang tepat dalam mempengaruhi khalayak sasaran dan bermakna positif sebagaimana yang dinyatakan oleh Leech (1966) dan Dyer (1982).
\end{abstract}

Kata kunci: kata kerja, hubungan leksikal, iklan, produk kecantikan. 


\title{
VERBS AND LEXICAL RELATION IN WOMEN'S BEAUTY PRODUCT ADVERTISEMENTS
}

\begin{abstract}
Commercial advertising is a form of persuasion to influence the opinions or buying decisions of the target audience. The advertisement of women's beauty products is one of them. Analysis was done on two famous brand ads, namely D'HERBS and Vida Beauty which focused on the verbs used in the slogan and description of face beauty products. This study is based on a study conducted by Leech (1966) on the verbs commonly used in advertisements. This study has two objectives, namely, identifying commonly used verbs and analysing lexical relationships that exist in common verbs. Four methods were applied - library research, screen shots, frequency analysis and text analysis. The findings show that among the verbs commonly used in facial beauty ads are "mencerah/mencerahkan", "merawat", "membantu" and "melembap/ melembapkan". The lexical relation formed eight groups of synonymy and three groups of antonymy. In conclusion, an advertiser had chosen the right words with the positive meanings to influence the target audience as stated by Leech (1966) and Dyer (1982).
\end{abstract}

Keywords: verbs, lexical relation, advertisements, beauty product

\section{Pengenalan}

Dyer (1982) mendefinisikan iklan sebagai "drawing attention to something or notifying or informing somebody of something" (hlm. 2). Definisi ringkas ini memperlihatkan fungsi iklan dalam masyarakat, iaitu usaha yang dilakukan dalam menarik perhatian khalayak tentang sesuatu. Definisi yang lebih lengkap pula diberikan oleh Business Dictionary yang menyatakan ia berbayar, tidak bersifat peribadi, komunikasi umum berhubungan sebab, barangan dan perkhidmatan, idea, organisasi dan tempat menerusi mel terus, bercetak, radio, televisyen dan internet. Danesi (2009) pula memberikan definisi yang mencakupi kedua-dua definisi yang diberikan, iaitu "service by means of a notice, such as a poster, newspaper display, or paid announcement in some electronic or digital medium, designed to attract public attention or patronage" (h/m. 13) yang secara ringkasnya merujuk pada pemberitahuan sama ada berbayar ataupun tidak dalam medium elektronik mahupun digital yang bertujuan mendapatkan perhatian khalayak. Menurut Danesi (2009) lagi, iklan di radio, televisyen atau internet dirujuk sebagai komersial. Iklan komersial adalah satu bentuk pembujukan yang hak penyiaran atau masanya dibeli daripada organisasi media dalam usaha mempengaruhi pandangan atau keputusan membeli pelanggan atau khalayak (Demers, 2005).

Sesuai dengan definisi iklan, iaitu bertujuan mendapatkan perhatian khalayak, iklan produk kecantikan wanita sememangnya bertujuan menarik perhatian wanita yang nalurinya mahu sentiasa kelihatan cantik. Menelusuri sejarah iklan berkaitan produk kecantikan wanita, Jones (dipetik dari Searing \& Zeilig, 2017), menyatakan sejarah iklan kosmetik dan penjagaan kulit telah berusia sekurang- 
kurangnya satu abad. Penyataan ini secara tidak langsung menggambarkan bahawa penggunaan produk kecantikan pastilah telah berlaku lebih awal daripada tempoh tersebut (Searing \& Zeilig, 2017). Iklan ini pula boleh ditemui di mana-mana sahaja seperti yang dinyatakan oleh DeBelen (2016), advertisements for makeup are everywhere, both on the street and online dan ini sekali lagi membuktikan bahawa wanita mementingkan kecantikan dan penampilan diri. Bagi wanita definisi kata cantik melibatkan tiga deria, iaitu lihat, rasa dan bau, iaitu sifat yang merupakan hasil hubungan sebab dan akibat (Zahid, 2018).

Sehubungan itu, bagi memperlihatkan tujuan iklan adalah untuk mempengaruhi khalayak sasarannya, analisis penggunaan kata kerja dan hubungan leksikal akan dilakukan pada iklan produk kecantikan wanita yang dihasilkan oleh dua buah syarikat tempatan, iaitu D'HERBS dan Vida Beauty.

\section{Sorotan Literatur}

Sorotan literatur ini akan hanya membincangkan kajian yang menggunakan iklan sebagai korpus analisis linguistik dan akan dibahagikan kepada dua senario, iaitu kajian dalam dan luar negara. Terdapat banyak kajian yang menggunakan korpus iklan yang dikaji dari pelbagai aspek, antaranya ialah retorik, stilistik dan pencemaran bahasa. Sehubungan itu, bagi mengecilkan skop sorotan, perbincangan akan hanya berfokus kepada kajian yang signifikan dan relevan dengan analisis yang sedang dilakukan, iaitu semantik leksikal. Walau bagaimanapun akan dibincangkan secara ringkas perkembangan awal analisis linguistik yang menjadi titik tolak kepada kajian ini.

Beberapa kajian di luar negara dilakukan antaranya oleh Leech (1966), Dyer (1982), Geis (1982), Coleman (1983), Cook (1992), Tanaka (1994), Emodi (2011), Maksimainen (2011), Chandra (2013), Kannan dan Tyagi (2013), Ke dan Wang (2013), Lazović (2014), Noor, Muhabat dan Kazemian (2015), Skorupa dan Dubovičienè (2015), Karang (2016), Dharmayanti, Tika dan Sudana (2017), dan Viramdami dan Himmawati (2017). Manakala kajian dalam negara dilakukan oleh Karim (1981, 1982, 1983, 1984, 1987 \& 1997), Omar (1984), Badarudin (1988), Khamis (1992), Christy (2010), Sidik (2012), Zahid dan Sidik (2012) dan Zahid (2018).

Bahasa iklan menurut Leech (1966) dalam bukunya English in Advertising: A Linguistic Study of Advertising in Great Britain ialah loaded language. Loaded language ( $\mathrm{hlm}$. 25) menurut beliau bermatlamat mengubah kehendak, pandangan atau sikap khalayak. Dalam kasus ini, beliau melakukan kajian tentang bahasa iklan di televisyen. Dalam perbincangannya Leech mengemukakan analisis nahu mencakupi peranan makna, frekuensi kata, iaitu kata adjektif dan kata kerja dalam iklan dan menghuraikan secara terperinci ciri-ciri penting bahasa iklan. Walaupun Leech menyenaraikan kata adjektif dan kata kerja yang dikatakan lazim digunakan dalam iklan di televisyen, kajian ini tidak memaparkan secara terperinci jumlah data yang digunakan, iaitu secara kuantitatif per se. Leech hanya menyatakan penggunakan sampel data berjumlah 617 iklan yang disiarkan dari Disember 1960 sehingga Mei 1961 (hlm. 5). Sungguhpun kajian Leech ini telah agak lama, kajian ini masih tetap dianggap bernilai tinggi dan sentiasa dirujuk kerana ia menyediakan satu katalog yang praktikal dalam memerikan karateristik iklan bahasa Inggeris 
(Bruthiaux 1996; Christy, 2010; Maksimainen, 2011). Malah menurut Bruthiaux kajian Leech ini merupakan percubaan pertama secara eksplisit menghubungkan parameter fungsi iklan dengan manifestasi linguistik.

Dyer (1982) pula membincangkan bahasa iklan sebagai satu bentuk komunikasi yang mencakupi pelbagai aspek. Antara yang dibincangkan ialah bahasa iklan daripada perspektif linguistik, iaitu pemilihan kata, ton suara, bahasa figuratif, peranan kata kunci selain memaparkan maklumat perkembangan iklan, definisi iklan dan sebagainya. Kandungan buku ini banyak memaparkan imej iklan bertujuan paparan contoh dan diskusi.

Sementara itu, Geis (1982) melakukan kajian yang hampir sama dengan Leech (1966), iaitu kajian bahasa iklan di televisyen. Walau bagaimanapun kajian beliau berfokus kepada teknik linguistik bahasa iklan yang menjadi pilihan penerbit komersial televisyen di Amerika. Sedikit berbeza dengan Leech, Geis tidak sahaja mengkaji bahasa pengiklan tetapi juga menganalisis jangkaan dan interprestasi pengguna terhadap bahasa iklan. Geis dalam kajiannya ini mengaplikasi pendekatan yang menghubungkan pengekod dan pentafsir kod, iaitu aspek pragmatik dengan menggunakan teori yang diusulkan oleh Grice (1975) tentang maksim. Hal yang sama dilakukan oleh Coleman (1983), Cook (1992) dan Tanaka (1994). Cook (1992) mengkaji bentuk linguistik paparan wacana iklan, iaitu visual, muzik dan fitur linguistik. Dalam kajian ini, beliau memperlihatkan kemampuan bahasa iklan yang sama seperti kemampuan teks dalam mencipta, membangkitkan dan mengukuhkan jenis sosial yang dominan sepertimana yang berlaku dalam penggunaan bahasa yang lain. Sementara Tanaka (1994) dengan menggunakan korpus iklan bahasa Inggeris dan Jepun telah menganalisis kefahaman pengguna terhadap mesej dalam iklan. Kajian ini memperlihatkan bahawa pentafsiran mesej dalam iklan melampaui proses mendekod dengan maksud khalayak perlu melakukan kesesuaian hubungan konteks dalam menyelesaikan masalah ketaksaan mesej. Tanaka mengaplikasikan teori Relevans oleh Sperber dan Wilson (1986) dalam analisisnya. Kesemua ini merupakan antara kajian awal yang menggunakan korpus iklan. Sementara itu, kajian tahun 2000-an antaranya dilakukan oleh Emodi (2011), iaitu berfokus pada 20 puluh buah iklan bahasa Inggeris. Emodi menganalisis keberkesanan bahasa dalam iklan dan memperlihatkan bahawa penggunaan makna konotatif, kata adjektif, kata ciptaan, kata yang dieja salah, perulangan, metafora, main kata-kata, kata yang tak wujud, penyataan taksa telah digunakan untuk mencapai objektif persuasif.

Maksimainen (2011) pula menganalisis slogan iklan yang mencakupi aspek sintaksis, struktur, nahu dan fitur leksikal slogan pembedahan refraktif mata. Analisis ini bertujuan mencari jawapan berhubungan dengan fitur distingtif yang dominan dalam slogan iklan yang berhubungan dengan dapatan Leech (1966) dan sarjana lain. Kajian ini memperlihatkan dapatan yang diperoleh tidak selari dengan perbincangan Leech tentang kata kerja yang digunakan atas beberapa sebab, iaitu korpus iklan yang berbeza, penggunaan bahasa yang berbeza berasaskan dekad, iaitu tempoh masa. Keselarian dapatan hanya ditemui pada penggunaan weasel, istilah teknikal dan saintifik, nama produk dan sebagainya dalam iklan.

Chandra (2013) menganalisis makna dalam slogan dengan menggunakan tiga puluh jenis slogan iklan bahasa Inggeris, iaitu tujuh slogan dari iklan perkhidmatan dan dua puluh tiga slogan daripada iklan produk. Dalam kajian ini, 
beliau mengaplikasikan kaedah kualitatif. Dapatan yang diperoleh memperlihatkan tujuh slogan tidak menggunakan bahasa figuratif, lapan slogan menggunakan hiperbola, sembilan slogan menggunakan personafikasi dan selebihnya menggunakan ironi, sinekdok, analogi dan metafora.

Seterusnya, dalam kajian berhubung penggunaan bahasa dalam iklan, Kannan dan Tyagi (2013) menyatakan bahawa kandungan visual dan reka bentuk dalam iklan mempunyai kesan yang sangat besar kepada pengguna. Walau bagaimanapun menurut mereka, penggunaan bahasa merupakan aspek yang membantu pengguna mengenal pasti dan mengingati sesuatu produk. Selain daripada itu, dapatan kajian ini juga menyatakan bahawa bahasa yang positif menjadikan produk tersebut menonjol daripada produk yang lain. Antara kata-kata yang digunakan mencakupi kata adjektif dan kata kerja, iaitu masing-masingnya good/better/best, great, real, easy; get, give, have, need dan sebagainya selain hiperbola, ayat-ayat pendek, eufemisme, mengelakkan makna negatif dan sebagainya.

Ke dan Wang (2013) melakukan kajian yang hampir sama dengan kajian yang dilakukan oleh Leech (1966) kecuali fokus kajian ini terhad kepada kata adjektif dan korpusnya berbeza. Data iklan bersumberkan majalah yang mencakupi antaranya iklan pakaian, kecantikan, minuman, makanan dan kelengkapan rumah. Kajian yang dilakukan ini menggunakan 100 slogan iklan bahasa Inggeris dengan berfokus pada lapan kata adjektif yang memperlihatkan frekuensi yang tinggi. Kata adjektif yang mencatatkan frekuensi yang tinggi ialah good, beautiful, real, better, best, great, perfect dan pure.

Lazović (2014) pula menganalisis iklan bank dalam talian. Iklan yang dikaji merupakan iklan dalam bahasa Inggeris yang dikumpul melalui laman sesawang bank-bank terkemuka di United Kingdom selama empat bulan, iaitu dari bulan Mei sehingga Ogos tahun 2012. Fokus kajian ini adalah pada karateristik elemen linguistik, iaitu ortografi, leksikal, nahu dan pragmatik. Objektif kajian ini adalah untuk memahami strategi linguistik yang digunakan dalam menarik perhatian pelanggan. Kajian ini mendapati antara strategi yang digunakan oleh pihak bank ialah menggunakan pelbagai aras bahasa, penggunaan huruf besar, kata yang memicu, iaitu penggunaan kata nama dan adjektif yang banyak berbanding kata kerja. Menurut kajian ini juga, kata kerja didapati kurang digunakan kerana kebanyakan iklan menggugurkan kata kerja di samping sifat iklan yang berbentuk ringkas.

Noor, Muhamat, dan Kazemian (2015) pula melakukan analisis semantik dalam slogan komersial televisyen. Kajian ini berfokus pada alat linguistik yang digunakan oleh penyusun iklan komersial televisyen dalam mempengaruhi audiens sasaran. Kajian ini mengaplikasikan teori Leech (1981) berkaitan asosiasi makna dan jenis-jenisnya. Analisis ini memperlihatkan kewujudan kepelbagaian strategi yang digunakan oleh penyusun iklan, iaitu makna konotatif, makna tematik, makna afektif emosi, makna kolektif, makna sosial stilistik dan makna refleksi.

Skorupa dan Dubovičienè (2015) menganalisis slogan iklan komersial dan sosial dari aspek karateristik semantik. Kajian ini menggunakan 110 iklan mencakupi 55 iklan komersial dan 55 iklan sosial. Kajian ini mendapati penggunaan yang kerap teknik bunyi dan bahasa kiasan adalah bertujuan untuk mudah diingati, 
menimbulkan daya tarikan dan menonjolkan jenama yang positif bagi iklan komersial. Sementara itu, situasi yang berbeza bagi iklan sosial kerana sifat iklan sosial yang berfungsi memberikan maklumat tentang sesuatu isu, iaitu tidak mewakili mana-mana jenama atau perkhidmatan.

Karang (2016) menganalisis jenis makna serta fungsi dalam aspek verbal dan jenis-jenis bahasa figuratif yang digunakan iklan produk kosmetik dalam majalah bahasa Inggeris. Kajian ini mengaplikasikan tiga buah teori, iaitu Leech (1966), Leech (1974) dan Perrine (2005). Dapatan kajian ini memperlihatkan dua perkara, iaitu penggunaan secara dominan makna denotatif yang berfungsi memberikan informasi kepada pengguna manakala jenis bahasa figuratif yang dominan ialah hiperbola.

Kajian Dharmayanti, Tika dan Sudana (2017) memperlihatkan perbezaan apabila fokus kajiannya adalah menganalisis ketaksaan leksikal dalam slogan iklan bahasa Inggeris jenama Unilever. Analisis ini mengaplikasi teori makna Leech (1974) dan teori ketaksaan leksikal Ullmann (1977) dengan menggunakan tiga belas slogan. Kajian ini mendapati kesemua slogan mengandungi kata yang taksa. Menurut kajian ini lagi, faktor leksikal dikatakan sebagai penyebab kepada ketaksaan berlaku, iaitu makna polisemi dan makna homonimi, masing-masingnya berjumlah enam dan tujuh dalam slogan yang dianalisis. Kajian ini juga mengkategorikan sepuluh slogan sebagai makna konseptual manakala slogan yang berbaki dikategorikan sebagai makna konotatif.

Analisis morpho-semantik jenama produk elektronik dengan menggunakan kaedah kualitatif dilakukan oleh Viramdani dan Himmawati (2017). Kajian ini menganalisis pembentukan kata jenama produk elektronik dan makna yang didenotasikan. Kajian ini memperlihatkan enam aspek pembentukan kata yang berlaku, iaitu mencakupi proses compounding, blending, clipping, coinage, abbreviation, dan acronym. Sementara itu dari aspek semantik, ditemui lima klasifikasi kerangka semantik bagi jenama produk, iaitu buah, tempat, orang, produk dan konsep.

Situasi yang berbeza berlaku di dalam negara, perkembangan kajian bahasa iklan agak lewat. Banyak ditemui perbincangan bahasa iklan dalam pembentangan kertas kerja, dijadikan bab dalam buku dan artikel dalam monograf yang dilakukan oleh Karim (1981, 1982, 1983, 1984, 1987, 1997). Karim dalam perbincangannya mengakui bahawa bahasa iklan merupakan satu perkembangan laras baru dalam negara, iaitu akibat pengaruh kapitalisme dan media massa luar di Malaysia. Walau bagaimanapun beliau mengakui bahawa bahasa iklan sebenarnya telah lama wujud dalam masyarakat Melayu. Penyataan ini dibuktikan dengan mengemukakan contoh penjualan ubat di pasar terbuka yang dikatakan sebagai kaedah tradisional dalam mengiklan. Menurut beliau lagi, bahasa iklan ini mempunyai keunikannya yang tersendiri. Dalam kajiannya, Karim secara umumnya membincangkan tentang tujuan iklan, karateristik bahasa iklan yang merangkumi pemilihan perkataan, ujaran performatif atau elemen imperatif, pembinaan aspek nahu dan semantik selain pencemaran bahasa yang berlaku. Menurut Khamis (1992), Karim membincangkan bahasa iklan semasa beliau melakukan kajian perkembangan bahasa Melayu. Sementara itu, Omar (1984) membincangkan pelbagai kaedah yang digunakan dalam bahasa iklan antaranya kaedah penyataan, kaedah perkaitan konsep, bentuk, konsep, nilai, norma dan penterjemahan, iaitu aspek retorik dalam bentuk buku. 
Buku ini dikatakan sebagai buku pertama yang membincangkan iklan di Malaysia. Badarudin (1988) pula, membincangkan bahasa iklan dari aspek retorik yang mencakupi teknik retorik berdasarkan Durand (1970) dan Leech (1966). Dalam tulisannya, Badarudin secara ringkas membincangkan juga tentang teknik yang dibincangkan oleh Omar (1984) dan menyimpulkan bahawa bahasa iklan sebagai bahasa yang kreatif serta dinamis dan memperlihatkan teknik metafora, metonimi, paralelisme, aliterasi, rima dan irama.

Kajian bahasa iklan dalam bahasa Melayu dan Inggeris yang disiarkan di televisyen dilakukan oleh Khamis (1992). Dalam kajian ini, Khamis menggunakan 72 iklan bahasa Inggeris dan 87 iklan bahasa Melayu sebagai data analisis. Kajian ini menggunakan kaedah kualitatif dan kuantitatif. Objektif kajian ini adalah untuk menganalisis penggunaan bahasa figuratif serta karateristik bahagian awal dan akhir bahasa iklan sebagai satu peristiwa bahasa. Hasil kajian ini mendapati dalam menyampaikan mesej dalam iklan, bahasa yang betul dan bahasa figuratif telah digunakan.

Christy (2010) pula melakukan kajian yang sedikit berbeza daripada pengkaji tempatan sebelumnya. Sungguhpun kajian ini masih berfokus kepada teknik literari dengan maksud yang hampir sama dengan teknik retorik, kajian ini merupakan kajian pertama yang menyentuh tentang frekuensi kata adjektif dan kata kerja seperti mana yang dibincangkan oleh Leech (1966). Dapatan kajiannya memperlihatkan persamaan dapatan dengan Leech, iaitu dari aspek frekuensi kata dan karateristik bahasa iklan. Ringkasnya, Christy berpegang kepada prinsip yang dinyatakan oleh Leech (1966) dan sarjana lain seperti Dyer (1982) bahawa bahasa iklan mempunyai ciri sarwajagat yang diguna pakai merentasi bahasa.

Kajian yang menggunakan iklan selanjutnya dilakukan oleh Sidik (2012). Kajian ini menganalisis domain semantik kata kerja dalam slogan produk kecantikan wanita, iaitu kecantikan muka dan badan. Data iklan yang dianalisis dikumpul dari majalah Mingguan Wanita yang diterbitkan sepanjang tahun 2006. Analisis yang dilakukan telah mengklasifikasikan kata kerja kepada dua sifat, iaitu kata kerja yang bersifat spesifik dan kata kerja yang bersifat umum. Kata kerja yang bersifat spesifik dengan kecantikan muka dan badan antaranya adalah "mencerahkan", "menghaluskan", "melangsingkan", "mengempiskan" dan sebagainya manakala kata kerja yang bersifat umum adalah "meneroka", "mengembalikan", "membantu" dan sebagainya. Kajian ini menyimpulkan bahawa kata kerja yang bersifat umum lebih dominan digunakan dalam iklan produk kecantikan.

Zahid dan Sidik (2012) telah menganalisis 66 kata kerja daripada 45 slogan iklan kecantikan muka. Analisis ini mengaplikasikan kaedah analisis komponen. Sama seperti kajian Sidik (2012), dapatan analisis memperlihatkan bahawa terdapat dua sifat kata kerja yang digunakan, iaitu kata kerja yang bersifat spesifik dan kata kerja yang bersifat umum. Kata kerja yang bersifat spesifik merujuk pada kata kerja yang berkolokasi dalam lingkungannya manakala sebaliknya bagi kata kerja yang bersifat umum. Didapati penggunaan kata kerja bersifat umum lebih dominan dalam iklan kecantikan muka. Antara kata kerja bersifat umum ialah "berhasil", "tercapai", "berkekalan", "menghargai" dan sebagainya.

Terakhir, kajian Zahid (2018) menggunakan iklan produk kecantikan wanita bagi mendapatkan definisi kata cantik secara lebih holistik. Kajian yang dilakukan ini 
memperlihatkan cakupan makna kata cantik dari perspektif orang Melayu berdasarkan analisis kolokasi. Kajian ini bertitik tolak daripada definisi dari kamus yang tidak memadai bagi membantu pengguna bahasa memahami makna kata cantik dari perspektif wanita. Analisis ini menggunakan iklan produk kecantikan wanita yang merangkumi kecantikan muka (kulit), bibir, rambut, kaki dan badan. Dapatan kajian ini menyimpulkan bahawa kecantikan dari sudut pandangan wanita adalah berkaitan dengan tiga deria, iaitu lihat, rasa dan bau.

Perbincangan sorotan literatur ini memperlihatkan bahawa kajian yang menggunakan korpus bahasa iklan agak banyak ditemui tetapi kajian yang per se mengkaji penggunaan kata kerja dari aspek semantik leksikal agak terhad. Kajian oleh Leech menjadi titik tolak kajian selepasnya walau bagaimanapun kajian selepas beliau telah mengaplikasikan teori dalam bidang pragmatik, iaitu maksim perbualan oleh Grice dan teori Relevans oleh Sperber dan Wilson selain aspek retorik dalam bahasa iklan. Berdasarkan sifat bahasa iklan itu sendiri yang merupakan bahasa kreatif dalam menyampaikan mesej sama ada bertujuan perkhidmatan ataupun komersial, kebanyakan kajian yang menggunakan korpus iklan lebih cenderung mengkaji bahasa figuratif dalam iklan, iaitu bidang retorik dan selebihnya kajian yang melibatkan kesalahan tatabahasa ataupun pencemaran bahasa. Kajian yang menyentuh aspek semantik tidak banyak ditemui sedangkan kajian tentang makna, iaitu ketepatan makna merupakan aspek yang penting dalam penyampaian maklumat dalam kasus iklan sebagaimana yang dikatakan oleh Emodi (2011) iaitu "semantic is one of linguistic forms that propel advertising to the desired height" (hlm. 317). Menurut Emodi (2011), pemilihan kata yang salah akan menyebabkan tiga senario, iaitu pertamanya memberikan makna yang tidak tepat, iaitu tidak selari dengan tujuan komunikasi; atau keduanya, mewujudkan kekaburan makna; atau ketiganya hanya dapat berfungsi sebahagiannya sahaja untuk mendukung makna yang dimaksudkan. Hal yang sama dinyatakan oleh Lazović (2014), iaitu kepentingan memilih kata kunci yang relevan dalam bahasa pemasaran kerana tindakan ini memicu perkaitan yang positif seperti yang dibincangkan antaranya oleh Leech (1966) dan Dyer (1982). Malah Dyer menyatakan kata-kata yang digunakan akan dapat mempengaruhi kepercayaan dan sikap khalayak (hlm. 140).

Sehubungan itu analisis semantik akan dilakukan dengan berfokus kepada penggunaan kata kerja dalam korpus iklan produk kecantikan wanita. Kata kerja menjadi fokus analisis bertitik tolak daripada penyataan Gärdenfors (2014) bahawa kata kerja mempunyai dua peranan utama, iaitu mendeskripsikan bagaimana sesuatu itu telah dan akan berlaku dan keduanya, bagaimana sesuatu itu berlaku atau akan berlaku. Hal yang sama juga dinyatakan oleh Yusof, Aman, Harun, Hamid dan Ma'alip (2010) bahawa kata kerja diutamakan dalam bahasa kerana kata kerja menentukan siapa yang melakukan (subjek), apa yang dilakukan dan terhadap apa perlakuan itu dilakukan (objek). Dalam bahasa iklan, kata kerja memperlihatkan proses yang akan berlaku apabila pengguna menggunakan sesuatu produk dan ini menjadi tarikan kepada pelanggan atau pengguna apabila membeli produk. Sehubungan itu, fungsi kata kerja dalam bahasa iklan merupakan aspek yang penting.

Kata kerja ini dikumpulkan daripada slogan dan penerangan iklan produk kecantikan wanita. Kata kerja yang digunakan dalam iklan ini lazimnya berperanan 
memperlihatkan makna kemampuan serta keberkesanan produk misalnya penggunaan kata membantu, menghalang, mengurangkan dan sebagainya. Kata kerja ini menjadi pemicu yang mempengaruhi tanggapan pengguna terhadap produk yang dipasarkan.

\section{Kerangka Teori}

Analisis yang dilakukan bertitik tolak daripada kajian yang telah dilakukan oleh Leech (1966) berhubung semantik leksikal dalam bahasa iklan. Leech membincangkan fungsi atribut kata kerja yang memperlihatkan sesuatu produk mempunyai sifat yang tersendiri atau bernilai kepada pelanggan. Dalam perbincangannya, Leech menyatakan kata kerja yang lazim dalam bahasa iklan mempunyai fungsi nahu dan makna, iaitu hubungan di antara pengguna dan produk mencakupi aspek pemilikan; idea pemilikan neutral; pemilikan berterusan; pemerolehan; pemberian; penggunaan dan kecenderungan mental terhadap produk. Penyataan Leech bertitik tolak daripada kajiannya yang menganalisis kata kerja yang lazim digunakan dalam iklan yang disiarkan di televisyen. Sehubungan itu, dalam kajiannya Leech telah menyenaraikan dua puluh kata kerja yang lazim digunakan (hlm. 154-155). Leech menyatakan kata kerja ini mempunyai pelbagai fungsi nahu dan makna. Salah satu fungsinya ialah menandakan hubungan di antara pengguna dan produk, iaitu mencakupi pemilikan produk - have, get, give, buy, keep; idea pemilikan neutral have dan have got; pemilikan berterusan - keep; pemerolehan - buy dan get; pemberian - give; penggunaan - take, use/uses dan have dan kecenderungan mental terhadap produk - like, love dan need; sementara choose dan taste tidak dinyatakan fungsinya secara jelas. Lanjutan itu analisis yang akan dilakukan ini dianggap bersifat separa pendua, iaitu menggunakan pakai buah fikiran Leech dalam memperlihatkan fungsi kata kerja dengan penambahan skop analisis iaitu, analisis frekuensi dan hubungan leksikal yang berlaku dalam kata kerja yang lazim digunakan dalam iklan produk kecantikan wanita dalam bahasa Melayu. Kajian ini tidak bersifat perbandingan kerana korpus bahasa serta medium yang berbeza selain data dan era yang digunakan juga tidak sama.

Dalam konteks analisis ini kata kerja dalam bahasa Melayu ditandainya dengan proses pengimbuhan dan makna yang dirujuk. Proses pengimbuhan mencakupi imbuhan awalan, akhiran, apitan dan sisipan (Tatabahasa Dewan, 2015). Walau bagaimanapun dalam konteks analisis ini, proses pengimbuhan yang terlibat hanya tiga proses yang pertama. Kata kerja yang telah dikenal pasti akan dianalisis dari aspek makna dengan menggunakan Kamus Dewan Edisi Keempat (2015) bagi mendapatkan makna denotatif manakala bagi memperoleh hubungan leksikal sinonimi dan antonimi, Tesaurus Bahasa Melayu Dewan (2015) dirujuk. Dalam proses mendapatkan hubungan makna ini, rujuk silang dilakukan kerana tidak kesemua hubungan leksikal ini tersenarai dalam satu entri yang sama. Hubungan leksikal terbentuk apabila sesuatu kata tersebut berada dalam domain semantik yang sama, iaitu satu medan yang di dalamnya mempunyai sejumlah kata yang berkongsi makna teras berhubung dengan sesuatu topik sebagaimana yang dinyatakan oleh Nida (1979), A semantic domain consists of any set of meanings which share a significant semantic feature in common. Lanjutan itu hubungan 
leksikal ini terbentuk apabila sesuatu kata tersebut berada di dalam satu medan yang sama. Walau bagaimanapun tidak ada kata yang akan bersinonim secara seratus peratus kerana setiap satu kata mempunyai fitur distingtifnya. Hal yang sama berlaku pada antonimi yang boleh sahaja dipertentangkan secara majmuk (Abdul Chaer, 2002).

\section{Objektif}

Kajian ini mempunyai dua objektif, iaitu:

1) mengenal pasti penggunaan kata kerja yang lazim dalam iklan produk kecantikan muka.

2) menganalisis hubungan leksikal kata kerja yang lazim dalam iklan produk kecantikan muka.

\section{Metodologi}

Empat metod diaplikasi dalam kajian ini, iaitu kajian pustaka, syot layar (screenshot), analisis frekuensi dan analisis teks. Kajian pustaka dilakukan bagi tujuan penyediaan sorotan kajian dan mengenal pasti trend semasa kajian. Data kajian pula dikumpulkan melalui syot layar iklan dari laman sesawang termasuk blog, Instagram (IG) dan Facebook (FB). Data yang siap dikumpul akan dilakukan analisis teks, iaitu mengenal pasti dan mengkategorikan kata kerja dalam produk kecantikan dua jenama yang menjadi korpus, iaitu D'HERBS dan Vida Beauty. Data terkumpul diberi label seperti berikut: DM1 yang bermaksud D- D'HERBS, M- muka, dan 1- data pertama dan seterusnya; manakala VM2, V- Vida Beauty, M- muka, dan 2- data kedua dan seterusnya.

Pengenalpastian dan pengiraan jumlah kata kerja dalam iklan dilakukan dengan menggunakan dua prosedur seperti berikut, iaitu pertamanya, setiap satu iklan yang sama bagi sesuatu produk dianggap sebagai satu data walaupun sesuatu iklan itu berulang dan disiarkan beberapa kali dalam tempoh kutipan data berlangsung. Kedua, jumlah iklan tidak secara mutlaknya menggambarkan jumlah kata kerja yang digunakan. Ini kerana terdapat slogan dan keterangan produk yang memperlihatkan penggunaan lebih daripada satu kata kerja, misalnya "mencerah", "menghilangkan", "membantu" dalam iklan Vida Beauty bagi produk yang bernama Extra Whitening Soap. Iklan ini mempunyai tiga kata kerja. Kesemua data iklan dimasukkan ke dalam perisian Excel 2010, iaitu aplikasi bagi menjana kekerapan penggunaan kata kerja. Seterusnya, dapatan analisis frekuensi dipaparkan dalam bentuk jumlah dan peratusan kekerapan. Dalam hal ini perisian Word Smith tidak digunakan atas empat sebab, pertamanya jumlah data yang masih dalam kawalan, iaitu tidak bersifat data raya (big data); kedua, penggunaan perisian Excel sudah memadai bagi mencapai objektif kajian; ketiga, hasil dapatan sama ada menggunakan perisian Word Smith atau Excel tetap mempunyai satu jawapan yang sama, iaitu frekuensi kata; dan keempat, perisian Word Smith melibatkan kos berbanding perisian Excel yang sedia ada dalam Microsoft Word. Sehubungan itu, dalam konteks analisis yang dilakukan, ia bukan merupakan isu utama walaupun kemungkinan kaedah yang digunakan ini dianggap agak ketinggalan bagi sesetengah 
pengkaji. Selanjutnya, ini diikuti dengan analisis teks sekali lagi bagi mengenal pasti hubungan leksikal kata kerja yang wujud melalui proses semakan dan rujuk silang dari Tesaurus Bahasa Melayu Dewan (2015) dan Kamus Dewan Edisi Keempat (2015). Hubungan leksikal yang akan dianalisis merujuk kepada hubungan makna sinonimi dan antonimi.

Kajian ini menganalisis kata kerja yang digunakan dalam slogan dan keterangan produk kecantikan keluaran D'HERBS dan Vida Beauty, iaitu dua buah syarikat tempatan yang ternama di Malaysia. Iklan produk kecantikan kedua-dua syarikat ini menjadi fokus kajian kerana kedua-duanya merupakan pengeluar produk kecantikan yang terkenal di Malaysia. Hal ini disokong dengan aktifnya mereka dalam alam maya bagi mempromosi produk selain mempunyai jumlah pengikut (follower) yang ramai, iaitu masing-masingnya 3.1 juta dan 2.1 juta selain jumlah hantaran (post) yang tinggi dalam akaun rasmi dan bilangan agen yang ramai. Data dikumpulkan daripada laman sesawang rasmi termasuk blog, Instagram (IG) serta Facebook (FB) kedua-dua buah syarikat dan agen sah kedua-dua syarikat pengeluar produk kecantikan ini yang berdaftar di Kuala Lumpur, Selangor dan Perak. Data dikumpulkan mulai tempoh Julai 2018 sehingga September 2018. Analisis berfokus pada produk kecantikan muka. Definisi muka dalam analisis ini mengguna pakai definisi Kamus Dewan Edisi Keempat (2015), iaitu definisi polisemi pertama bahagian kepala di sebelah hadapan dari dahi hingga ke dagu. Kata kerja yang dianalisis ialah sejumlah 205 daripada 70 data iklan yang terkumpul.

Bagi tujuan pengehadan kajian, analisis yang dilakukan tidak akan menyentuh strategi pemasaran produk, imej dan bahan lisan, iaitu naratif yang mengiringi slogan dan keterangan produk. Hanya produk khusus untuk muka sahaja yang akan dianalisis walaupun diketahui bahawa kedua-dua buah syarikat, iaitu D'HERBS dan Vida Beauty mengeluarkan pelbagai produk kecantikan untuk wanita.

\section{Dapatan dan Perbincangan}

Analisis frekuensi yang dilakukan memperlihatkan dapatan kata kerja bagi keduadua jenama, iaitu D'HERBS dan Vida Beauty yang berjumlah 205 dengan kata kerja yang lazim digunakan adalah "mencerah / mencerahkan", 36 (17.56\%); diikuti dengan "merawat", 27 (13.17\%), "membantu", 25 (12.20\%) dan "melembap" / "melembapkan", 16 (7.81\%). Sementara itu, kata kerja yang berbaki memperlihatkan julat kekerapan di antara 5-9, (2.44 - 4.39\%) - masing-masingnya disusun berdasarkan jumlah kekerapan rendah kepada jumlah kekerapan tinggi, iaitu kata kerja "membuang", "menganjal/menganjalkan", "menghilangkan" dan "menyingkirkan"; "menaik"/"menaikkan" dan "mengurangi"/"mengurangkan"; "membersihkan"/"membersihkan" dan "menggebukan"; "mengatasi"; dan "menyegarkan". Manakala kata kerja yang berbaki memperlihatkan julat kekerapan di antara 1-4, iaitu (0.49\% - 1.95\%). Dapatan analisis frekuensi ini dipaparkan dalam Jadual 1. Jadual 1 mempunyai tiga kolum, kolum 1 - Kata Kerja Jenama Produk; kolum 2 - Kekerapan dan kolum 3 - Peratusan. 
Jadual 1

Kekerapan kata kerja dalam produk kecantikan D'HERBS dan Vida Beauty

\begin{tabular}{|c|c|c|}
\hline Kata Kerja D'HERBS + Vida Beauty & Kekerapan & Peratusan (\%) \\
\hline Melembap, Melembapkan & 16 & 7.81 \\
\hline Melindungi & 2 & 0.98 \\
\hline Mematikan & 2 & 0.98 \\
\hline Membantu & 25 & 12.20 \\
\hline Memberi & 2 & 0.98 \\
\hline Membersih, Membersihkan & 7 & 3.42 \\
\hline Membina & 1 & 0.49 \\
\hline Membuang & 5 & 2.44 \\
\hline Memelihara & 1 & 0.49 \\
\hline Memperbaiki & 1 & 0.49 \\
\hline Memudarkan & 1 & 0.49 \\
\hline Memutihkan & 1 & 0.49 \\
\hline Menaikkan, Naik & 6 & 2.93 \\
\hline Menanggalkan & 2 & 0.98 \\
\hline Menganjal, Menganjalkan & 5 & 2.44 \\
\hline Mencantikan & 3 & 1.46 \\
\hline Mencerah, Mencerahkan & 36 & 17.56 \\
\hline Mencuci & 3 & 1.46 \\
\hline Mengatasi & 8 & 3.90 \\
\hline Mengawal & 4 & 1.95 \\
\hline Mengecutkan & 1 & 0.49 \\
\hline Mengembalikan & 4 & 1.95 \\
\hline Mengeringkan & 1 & 0.49 \\
\hline Menggebukan & 7 & 3.41 \\
\hline Menghaluskan & 2 & 0.98 \\
\hline Menghilangkan & 5 & 2.44 \\
\hline Mengurangi, Mengurangkan & 6 & 2.93 \\
\hline Meninggalkan & 1 & 0.49 \\
\hline Meningkatkan & 1 & 0.49 \\
\hline Menjadikan & 1 & 0.49 \\
\hline Menyegarkan & 9 & 4.39 \\
\hline Menyerikan & 1 & 0.49 \\
\hline Menyingkirkan & 5 & 2.44 \\
\hline Meratakan & 1 & 0.49 \\
\hline Merawat & 27 & 13.17 \\
\hline Meremajakan & 1 & 0.49 \\
\hline Nampak & 1 & 0.49 \\
\hline Jumlah & 205 & 100 \\
\hline
\end{tabular}


Dapatan frekuensi dalam Jadual 1 hanya memaparkan maklumat umum sahaja, iaitu jumlah kata kerja yang berulang. Jadual ini tidak memaparkan maklumat hubungan leksikal yang kemungkinannya wujud di antara sejumlah kata yang berulang tersebut.

Sehubungan itu, analisis seterusnya dilakukan bagi memperlihatkan hubungan leksikal kata kerja yang berlaku di antara sejumlah kata kerja yang telah digunakan. Hubungan leksikal yang akan dibincangkan ini mencakupi dua hubungan makna, iaitu sinonimi dan antonimi. Paparan Jadual 2 yang berikut memaparkan hubungan leksikal sinonimi yang berlaku dalam data iklan yang dianalisis. Paparan maklumat dalam Jadual 2 disusun berdasarkan kekerapan tertinggi kepada kekerapan terendah. Jadual 2 dipaparkan dalam empat kolum, kolum 1- Bilangan; kolum 2 - Kata; kolum 3 - Jumlah dan kolum 4 - Peratusan.

Jadual 2

Hubungan leksikal - sinonimi

\begin{tabular}{llcc}
\hline Bil. & \multicolumn{1}{c}{ Kata } & Jumlah & Peratusan \\
\hline 1. & Mencerah/mencerahkan & 36 & 17.56 \\
& Memutihkan & 1 & 0.49 \\
& Menyerikan & 1 & 0.49 \\
& Jumlah & 38 & 18.54 \\
\hline 2. & Merawat & 27 & 13.17 \\
& Mengawal & 4 & 1.95 \\
& Memperbaiki & 1 & 0.49 \\
& Memelihara & 1 & 0.49 \\
& Jumlah & 33 & 16.10 \\
\hline 3. & Membantu & 25 & 12.20 \\
& Memberi & 2 & 0.98 \\
& Jumlah & 27 & 13.18 \\
\hline 4. & Menggebukan & 7 & 3.41 \\
& Menghaluskan & 2 & 0.98 \\
& Jumlah & 9 & 4.40 \\
\hline 5. & Membersih/membersihkan & 7 & 3.41 \\
& Mencuci & 3 & 1.46 \\
& Jumlah & 10 & 4.48 \\
\hline 6. & Menaik/menaikkan & 6 & 2.93 \\
& Meningkatkan & 1 & 0.49 \\
& Jumlah & 7 & 3.42 \\
\hline 7. & Membuang & 5 & 2.44 \\
& Menghilangkan & 5 & 2.44 \\
& Menyingkirkan & 5 & 2.44 \\
& Jumlah & 15 & 7.32 \\
\hline 8. & Mengecutkan & 1 & 0.49 \\
& Mengeringkan & 2 & 0.49 \\
& Jumlah & 0.98 \\
\hline
\end{tabular}


Analisis hubungan leksikal sinonimi memperlihatkan terbentuknya lapan kelompok kata yang bersinonim. Penggunaan kata yang bersinonim ini digunakan sama ada secara bertukar ganti di antara satu sama lain ataupun digunakan secara serentak dalam slogan dan keterangan produk. Didapati pengiklan memperlihatkan kecenderungan penggunaan kata kerja yang tertentu, iaitu dalam kasus ini ditandai dengan jumlah kekerapan perulangan kata kerja yang berkenaan. Kesemua makna kata kerja yang digunakan ini berciri positif, iaitu hasil penggunaan produk akan dapat mencantikkan muka. Makna yang positif ini merupakan "senjata" pengiklan dalam mempengaruhi pelanggan dalam menggunakan produk.

Kelompok sinonim yang pertama memperlihatkan kata kerja "mencerah"/ "mencerahkan" menjadi pilihan utama berbanding dengan dua kata yang lain, iaitu "memutihkan" dan "menyerikan". Kelompok kedua, memperlihatkan kata kerja "merawat" menjadi pilihan berbanding dengan empat kata lainnya, iaitu "menyegarkan", "mengawal", "memperbaiki" dan "memelihara". Sementara kelompok ketiga, kata kerja "membantu" menjadi pilihan berbanding dengan kata "memberi"; kelompok keempat, kata kerja "menggebukan" dipilih berbanding dengan kata "menghaluskan"; kelompok kelima, kata kerja "membersih"/ "membersihkan" menjadi pilihan berbanding dengan kata "mencuci"; kelompok keenam, kata kerja "menaik"/"menaikkan" menjadi pilihan berbanding dengan kata "meningkatkan"; kelompok ketujuh dan kelapan, tidak memperlihatkan kata kerja yang menjadi pilihan utama, masing-masingnya memperlihatkan ketiga-tiga kata kerja "membuang", "menghilangkan" dan "menyingkirkan" dan kedua-dua kata "mengecutkan" dan " mengeringkan" digunakan dengan kadar jumlah yang sama. Dua kelompok kata sinonim yang terakhir, iaitu kelompok tujuh dan lapan didapati kurang signifikan dalam memperlihatkan pilihan kata bahasa pengiklan.

Jadual 2 memperlihatkan kata "mencerah/mencerahkan" menjadi pilihan utama pengiklan, iaitu berulang sebanyak $36,(17.56 \%)$. Kata mencerahkan menurut Tesaurus Bahasa Melayu Dewan $(2015, \mathrm{hlm}$. 156) bersinonim dengan kata memutihkan dan menyerikan. Walaupun kedua-dua kata yang terakhir ini hadir dalam kelompok yang sama erti tetapi kata "mencerahkan" menjadi pilihan utama pengiklan kerana menurut Kamus Dewan (2015, hlm. 269) kata "mencerah/mencerahkan" mencakupi makna yang lebih holistik dengan maksud berseri, tidak muram, menyerikan, tidak hitam (dan tidak putih benar). Ini berbeza dengan makna kata kerja "memutihkan" yang hanya membawa maksud menjadikan putih dan kata "menyerikan" dengan hanya maksud menjadikan berseri. Kedua-dua makna kata kerja "memutihkan" dan "menyerikan" mempunyai makna yang terhad dalam konteks produk kecantikan muka. Pengguna produk kecantikan, tentu sekali menginginkan satu produk yang fungsinya bukan sahaja satu tetapi mempunyai kemampuan yang lebih daripada satu. Oleh kerana itu lazim ditemui iklan atau slogan sesuatu produk yang menggunakan tagline 2 dalam 1; 3 dalam 1; beli 2 dapat 3 dan sebagainya yang membawa makna memperoleh sesuatu dengan ekstra. Dalam konteks produk kecantikan wanita, pengiklan perlu bijak dalam memilih kata kerja yang menggambarkan kemampuan produk yang dipasarkan oleh mereka. Kata "mencerah/mencerahkan" menjadikan pengguna yang tidak memiliki kulit muka yang putih, akan menjadi cerah sekali gus berseri dan tidak kusam manakala 
pengguna yang sedia memiliki kulit muka yang putih akan menjadi lebih berseri. Ini yang dimahukan oleh wanita dalam produk kecantikan yang digunakan.

Kelompok sinonim kedua, kata "merawat" bermaksud memelihara, menyelenggarakan, membela, menjaga (orang sakit dII) dengan memberi ubat dsb (Kamus Dewan, 2015 hlm. 1296). Kata ini memperlihatkan perulangan sebanyak 27, (13.17\%). Kata ini bersinonim dengan kata "memelihara" (Tesaurus Bahasa Melayu Dewan, $2015 \mathrm{hlm}$. 714) dan secara rujuk silang bersinonim dengan kata "mengawal" (hlm. 638), "memperbaiki" dengan maksud menyembuhkan (hlm. 858). Dalam konteks produk kecantikan, "merawat" berlaku akibat muka telah mengalami "kerosakan". Sehubungan itu perbuatan "merawat" bertujuan memastikan keadaan semasa muka kembali baik atau pulih melalui khasiat yang diperoleh melalui penggunaan produk. Pengiklan dalam konteks ini sedia maklum akan kondisi muka yang bermasalah bagi sesetengah wanita. Sehubungan itu, dalam usaha menarik perhatian khalayak sasaran mereka, iaitu wanita yang menghadapi masalah kulit muka, pengiklan menggunakan kata "merawat" dengan maksud memberikan harapan bahawa masalah kondisi muka yang rosak dapat dipulihkan. Situasi ini lazim dipaparkan apabila pengiklan menerangkan kehebatan produk mereka melalui penggunaan bahan-bahan yang digunakan. Bahan-bahan yang digunakan untuk menghasilkan produk inilah yang dirujuk sebagai "ubat" yang akan membantu pengguna yang menhadapi masalah kulit muka.

Kelompok sinonim ketiga, kata "membantu" yang menurut Kamus Dewan $(2015, \mathrm{hlm}$. 126) bermaksud memberikan bantuan, menolong, menyokong. Definisi kata ini sekali gus menjelaskan bahawa produk yang digunakan mempunyai potensi untuk menyelesaikan masalah kecantikan pengguna. Kata ini menjanjikan kepada pengguna bahawa mereka akan diberikan pertolongan dalam semua aspek masalah kecantikan yang dihadapi. Secara tidak langsung makna kata ini telah memberikan janji dan harapan kepada pengguna bahawa mereka akan dibantu dalam penyelesaian masalah yang dihadapi. Pengiklan dalam konteks ini telah memperlihatkan perulangan penggunaan kata ini sebanyak $25,(12.20 \%)$. Rujuk silang yang dilakukan memperlihatkan kata ini bersinonim dengan kata "memberikan" (Tesaurus Bahasa Melayu Dewan, 2015 hlm. 1046). Penggunaan kata "membantu" ternyata menjadi pilihan pengiklan kerana makna kata ini yang bermaksud penyelamat dalam situasi empunyai diri yang bermasalah sudah gagal menyelesaikan masalah mereka sendiri sehingga memerlukan bantuan produk dalam penyelesaian masalah mereka. Dalam kasus ini kata "memberi" tidak menjadi pilihan kerana makna kata ini yang kurang memberikan impak makna menolong secara eksplisit.

Seterusnya kelompok makna sinonim keempat, kata "menggebukan" dengan kata dasarnya "gebu" bermaksud penuh berisi, licin dan halus kulitnya (Kamus Dewan, $2015 \mathrm{hlm}$. 441). Kata ini ini menjadi pilihan pengiklan berbanding dengan kata sinonimnya "menghaluskan". Ini kerana makna kata "gebu" lebih mencakupi konsep makna yang luas berbanding "halus". "Gebu" tidak bermaksud gemuk sebaliknya penuh berisi yang berantonim dengan lisut, iaitu kecut yang menberikan kesan kendur dan berkedut berbanding penuh berisi yang memberikan kesan tegang sekali gus licin dan halus. Sehubungan itu, pengiklan ternyata bijak dalam melakukan pemilihan kata dalam menarik perhatian wanita. 
Kelompok sinonim kelima, "membersih/membersihkan" bermaksud menjadikan sesuatu bersih (Kamus Dewan, hlm, 172). Kata ini menjadi pilihan pengiklan, iaitu berulang sebanyak 7 (3.42\%). Walaupun kata ini bersinonim dengan kata "mencuci" (Tesaurus Bahasa Melayu Dewan, 2015, hlm. 104), kata "membersih/membersihkan" ternyata menjadi pilihan kerana kolokasi yang berlaku apabila menggunakan kata "bersih", maka kata yang dihubungkannya ialah "putih" "putih bersih". Tidak berlaku kasus "putih cuci" tetapi "cuci bersih". Ini memungkinkan pengiklan lebih menekankan makna bersih yang digunakan dalam iklan produk kecantikan muka.

Kelompok sinonim keenam, "menaik/menaikkan" yang bermaksud menjadikan naik (tinggi) (Kamus Dewan, 2015, hlm.1066). Kata ini menjadi pilihan pengiklan dalam produk kecantikan muka kerana sering kali kata "menaikkan" ini dikolokasi dengan kata "seri", iaitu "menaikkan seri muka". Tidak berlaku dalam kasus kecantikan muka, kata "meningkatkan" digunakan dengan maksudkan seri muka yang dirujuk.

Kelompok sinonim ketujuh dan kelapan tidak memperlihatkan perbezaan yang siginifikan, sehubungan dengan itu, kedua-dua kelompok ini tidak dibincangkan dari aspek maknanya.

Sementara itu, hubungan leksikal antonimi dapat dilihat pada Jadual 3 yang berikut, iaitu kata kerja yang digunakan sama ada secara pilihan, iaitu salah satu kata kerja ini digunakan dalam iklan atau pun berlaku kasus, kedua-dua hubungan leksikal ini hadir secara serentak dalam slogan dan keterangan iklan. Paparan dapatan frekuensi ini disusun berdasarkan jumlah kekerapan tertinggi kepada jumlah kekerapan terendah. Jadual 3 dipaparkan dalam empat kolum, kolum 1 - Bilangan; kolum 2 - Kata Kerja; kolum 3 - Jumlah dan kolum 4 - Peratusan.

Jadual 3

Hubungan leksikal - antonimi

\begin{tabular}{llcc}
\hline Bil. & \multicolumn{1}{c}{ Kata Kerja } & Jumlah & Peratusan \\
\hline 1. & Mencerah/mencerahkan & 36 & 17.56 \\
& Memutihkan & 1 & 0.49 \\
& Menyerikan & 1 & 0.49 \\
& Memudarkan & 1 & 0.49 \\
2. Melembap/melembapkan & 16 & 7.81 \\
3. Mengeringkan & 1 & 0.49 \\
Menaikkan/naik & 6 & 2.93 \\
& Meningkatkan & 1 & 0.49 \\
& Mengurangi/mengurangkan & 6 & 2.93 \\
\hline
\end{tabular}

Jadual 3 memperlihatkan kata yang berantonim dapat dikelompokkan kepada tiga. Kelompok pertama memperlihatkan hubungan pertentangan berkaitan dengan warna pada kulit muka; kelompok kedua berkaitan dengan kadar kelembapan kulit muka dan kelompok yang ketiga berhubungan dengan usaha memperbaiki keadaan kulit muka.

Ketiga-tiga kasus kelompok antonim ini memperlihatkan bahawa kata yang mempunyai makna positif dipentingkan oleh pengiklan dalam menarik perhatian 
khayalak penggunanya. Ini bertepatan dengan perbincangan antaranya Leech (1966), Dyer (1982), Emodi (2011) dan Lazović (2014). Pengiklan akan lebih cenderung menggunakan kata yang bermaksud positif bagi memberikan impak kepada produk yang dihasilkan dan memberikan keyakinan kepada pengguna. Katakata yang bersifat positif ini secara tidak langsung memberikan motivasi kepada pengguna, iaitu semangat dan harapan bahawa mereka difahami dan akan dibantu dalam masalah kecantikan muka yang dihadapi.

\section{Kesimpulan}

Kata kerja dalam slogan dan penerangan iklan digunakan oleh pengiklan secara terancang, iaitu dari aspek makna yang dirujuk bagi menarik perhatian khalayak sasarannya. Ini bererti pemilihan kata kerja tidak dilakukan secara sewenangsewenangnya. Menurut Lazović (2014) syarikat pengeluar produk akan memilih kata yang signifikan dan relevan dengan produk yang dipasarkan bagi menarik perhatian khalayak sasaran mereka Dalam konteks produk kecantikan wanita, iaitu muka, kata kerja yang digunakan merupakan kata kerja yang mempunyai makna memberikan harapan atau janji yang dirujuk sebagai weasel, iaitu muslihat yang mendorong pengguna berfikir tentang kemampuan atau manfaat penggunaan produk walaupun makna kata tersebut tidak semestinya benar dalam konteks yang dirujuk (Synovitz \& Larson, 2018). Ini bererti harapan dan janji akan kebekesanan produk tidak dapat dipastikan. Ini kerana sesetengah produk yang dipasarkan tidak melalui proses penyelidikan dan ada pula produk yang belum atau tidak mendapat kelulusan daripada Kementerian Kesihatan Malaysia (KKM). Kepentingan adanya penyelidikan dan kelulusan KKM sebelum memasarkan sesuatu produk ada dinyatakan melalui laman sesawang SIRIM Berhad (2019) tentang kepentingan R\&D dalam kosmetik.

Dapatan analisis memperlihatkan pengiklan bijak dalam memilih kata kerja yang digunakan dalam slogan dan keterangan produk, iaitu kata yang signifikan dan relevan dengan produk yang dipasarkan. Frekuensi yang tinggi diperlihatkan dengan penggunaan kata "mencerah/mencerahkan", "merawat" dan "membantu" yang merujuk kepada makna kemampuan produk tersebut bagi mencantikkan muka. Hubungan leksikal sinonimi pula memperlihatkan pilihan utama kata yang digunakan oleh pengiklan, misalnya kata "mencerahkan" berbanding "menyerikan"; "merawat" berbanding "memelihara"; "membantu" berbanding "memberi"; "menggebukan" berbanding "menghaluskan"; "membersihkan" berbanding "mencuci" dan "menaik"/menaikkan" berbanding "meningkatkan". Kesemua makna kata ini mendukung makna yang positif. Hal yang sama untuk antonimi, iaitu makna yang berciri negatif dielakkan penggunaannya. Dapatan analisis memperlihatkan kata "memudarkan" dan "menggeringkan" tidak menjadi pilihan.

Penggunaan kata kerja ini menjadi daya tarikan kepada wanita untuk mencuba produk yang dipasarkan apatah lagi kadang kala iklan tersebut disokong dengan testimoni pengguna. Dalam kasus ini pengiklan ternyata menggunakan strategi pemasaran yang dirujuk sebagai AIDA, attention dengan maksud menarik perhatian pengguna; interest, meningkatkan minat; desire, keinginan dan action, melakukan tindakan, iaitu pembelian (Hadiyati, 2016). Sehubungan itu, kajian Leech (1966) tentang fungsi atribut kata kerja dalam bahasa iklan memperlihatkan 
pengiklan sememangnya bijak melakukan pemilihan kata kerja yang sesuai dengan produk yang dipasarkan bagi memastikan produk mereka terus mendapat sambutan.

\section{Rujukan}

Badarudin, N. B. (1988). Retorik dalam bahasa pengiklanan. Jurnal Dewan Bahasa, 32(6), 415-422.

Bruthiaux, P. (1996). The discourse of classified advertising: exploring the nature of linguistics simplicity. New York, NY: Oxford University Press.

Business Dictionary. (n.d.). Retrieved February 1, 2019, from http://www.business dictionary.com

Chaer, A. (2002). Pengantar semantik bahasa Indonesia. Jakarta, Indonesia: Rineka Cipta.

Chandra, E. N. (2013). Meaning analysis of English slogans advertisment. DEIKSIS, 5(1), 11-25.

Christy, J. L. J. E. (2010). Literary devices and vocabulary frequency use in Malaysian radio advertisment. Unpublished Master Dissertation, Universiti Malaya.

Coleman, L. (1983). Semantics and prosodic manipulation in advertising. In H. J. Richard (Ed.), Information processing research in advertising (pp. 214-240). Hillsdale, GJ: Lawrence Erlbaum.

Cook, G. (1992). The discourse of advertising. London, UK: Routledge.

Danesi, M. (2009). Dictionary of media and communications. London, UK: M.E. Sharpe.

DeBelen, B. (2016). Marketing makeup: How advertising cosmetics affects consumers. $\quad$ Retrieved from https://digitalcommons.salemstate.edu/honors_theses/131

Demers, D. (2005). Dictionary of mass communication \& media research. New York, NY: Marquette Books.

Dharmayanti, G. A. D., Tika, K., \& Sudana, G. P. (2017). Lexical ambiguity in English advertisment slogans of Unilever products. Jurnal Humanis, 19, 72-79.

Dyer, G. (1982). Advertising as communication. New York, NY: Methuen \& Co. Ltd.

Effective Advertising Words (2013). Systemagic productions. Retrieved from http://systemagicmotives.com/Effective

Emodi, L. N. (2011). A semantic analysis of the language of advertising. An International Multidisciplinary Journal, Ethiopia, 5(4), 316-326.

Gärdenfors, P. (2014). The geometry of meaning: semantics based on conceptual spaces. Cambridge, UK: The MIT Press.

Geis, M.L. (1982). The language of television advertising. New York, NY: Academic Press.

Hadiyati, E. (2016). Study of marketing mix and aida model to purchasing online product in indonesia. British Journal of Marketing Studies, 4(7), 49-62.

Jones, G. (2010). Beauty imagined. Oxford, UK: Oxford University Press.

Kamus Dewan Edisi Keempat (2015). Kuala Lumpur, Malaysia: Dewan Bahasa dan Pustaka. 
Kannan, R., \& Tyagi, S. (2013). Use of language in advertisements. English for Specific Purposes World, 37(13), 1-10.

Karang, N. N. A. S. (2016). Analysis of cosmetic product advertisments. E-Jurnal Humanis, 15(1), 72-79.

Karim, N. S. (1983). Laras iklan dalam bahasa Malaysia. Monograf rancangan bahasa Melayu, Universiti Malaya.

Karim, N. S. (1981). Bahasa Malaysia and the language of advertisment. In Asmah Haji Omar \& Noor Ein Md. Noor (Eds.), National language as medium of instruction (pp. 315-325). Kuala Lumpur, Malaysia: Dewan Bahasa dan Pustaka.

Karim, N. S. (1987). Kesalahan bahasa dalam konteks pemakaian kebudayaan dan sosial (beberapa aspek penggunaan bahasa dalam iklan). In Abdullah Hassan, Hasnah Ibrahim, \& Mashudi Kader (Eds.). Kesalahan Bahasa Dalam Bahasa Melayu (pp. 483-489). Kuala Lumpur, Malaysia: DBP.

Karim, N. S. (1997). Bahasa Melayu dalam iklan: Cabaran era globalisasi. Forum UMUSU. Universiti Malaya.

Karim, N. S. (1982). Kesalahan bahasa dalam konteks pemakaian kebudayaan dan sosial: Beberapa aspek penggunaan bahasa dalam laras iklan. Seminar Kesalahan-Kesalahan Penggunaan Bahasa di dalam Bahasa Malaysia, Pulau Pinang.

Karim, N. S. (1984). Penggunaan bahasa Malaysia dalam pengiklanan daripada perspektif pemikiran dan budaya Melayu. Bengkel penggunaan bahasa Malaysia dalam pengiklanan, Kuala Lumpur, Malaysia.

Ke, Q., \& Wang, W. (2013). The adjective frequency in advertising english slogans. Theory and Practice in Language Studies, 3(2), 275-284.

Khamis, H. R. (1992). The language of television advertisement in Malay and English. Unpublished Master Dissertation, Universiti Malaya.

Lazović, V. (2014). The language of online bank advertisments in English. Journal of English For Specific Purposes at Tertiary Level, 2(1), 88-104.

Leech, G. (1966). English in advertising: A linguistic study of advertising in Great Britain. London: Longman.

Maksimainen, V. (2011). A linguistic analysis of slogan used in refractive surgery advertising. Unpublished Doctoral Dissertation, University of Tampere.

Nida, E.A. (1979). A componential analysis of meaning: an introduction to semantic structures. London, UK: University Press.

Noor, M., Mustafa, R.E., Muhabat, F., Kazemian, B. (2015). The language of TY commercials slogans: A semantic analysis. Communication and Linguistics Studies, 1(1), 7-12

Omar, H. A. (1984). Bahasa iklan perniagaan: Satu kajian bahasa retorik. Kuala Lumpur: Dewan Bahasa dan Pustaka.

Searing, C. \& Zeilig, H. (2017). Fine lines: cosmetic advertising and the perception of ageing female beauty. International Journal of Ageing and Later Life, 11(1), 7-36.

Sidik, F. (2012). Kata kerja dalam slogan iklan kecantikan wanita: analisis semantik leksikal. Unpublished Master Dissertation, Universiti Malaya. 
SIRIM Berhad. (2019). Retrieved from http://www.sirim.my/index.php/mediagallery/press-releases/press-releases-2018/1390-q-a-kepentingan-r-ddalam-kosmetik.

Skorupa, P., \& Dubovičienè, T. (2015). Linguistic characteristics of commercial and social advertising slogans. Santalka: Filologija, Edukologija/Coactivity: Philology, Educology, 23(2), 108-118

Synovitz, L. B., \& Larson, K. L. (2018). Consumer health \& integrative medicine: A holistic view of complementary and alternative medicine practice (2nd ed.). Burlington MA: Jones \& Barlett Learning.

Tanaka, K. (1994). Adverstising Language: A pragmatic approach to advertisments In Britain and Japan. London: Routledge.

Tatabahasa Dewan Edisi Ketiga. (2015). Kuala Lumpur, Malaysia: Dewan Bahasa dan Pustaka.

Tesaurus Bahasa Melayu Dewan (2015). Kuala Lumpur, Malaysia: Dewan Bahasa dan Pustaka.

Viramdani, I. R., \& Himmawati, D. R. (2017). Morpho-semantic analysis in electronic product brands. Language Horizon, 5(1), 1-11.

Yusof, M., Aman, R., Harun, K., Hamid, S., \& Ma'alip, S. (2010). Perkaitan semantik kata kerja bahasa Banjar Kuala: satu analisis varian Kuin, Banjamasin. Jurnal Melayu, 5, 87-102.

Zahid, I., \& Sidik, F. (2012) analisis komponen makna kata kerja dalam slogan iklan produk kecantikan muka. Jurnal Bahasa, 12(2), 256-283.

Zahid, I. (2018). Definisi kata cantik: Analisis kolokasi. Issues in Language Studies, 7(1), 12-36.

\section{Penghargaan}

Jasminerah Abdul Jalil, pelajar Akademi Pengajian Melayu (APM), Universiti Malaya (UM), Kuala Lumpur, Malaysia bagi kerja-kerja pengumpulan dan pemprosesan data. 